\title{
POSTN wt Allele
}

National Cancer Institute

\section{Source}

National Cancer Institute. POSTN wt Allele. NCI Thesaurus. Code C101423.

Human POST N wild-type allele is located in the vicinity of $13 q 13.3$ and is approximately $47 \mathrm{~kb}$ in length. This allele, which encodes periostin protein, is involved in the regulation of cell adhesion. 